\title{
Methotrexate-loaded nanoparticles ameliorate experimental model of autoimmune arthritis by regulating the balance of interleukin-17-producing $T$ cells and regulatory $T$ cells
}

Jin-Sil Park ${ }^{1,5+}$, Donghyun Lee ${ }^{2,3+}$, SeungCheon Yang ${ }^{1,5}$, Ha Yeon Jeong ${ }^{1,2,3,5}$, Hyun Sik Na ${ }^{1,2,3,5}$, Keun-Hyung Cho ${ }^{1,2,3,5}$, JeongWon Choi ${ }^{1,5}$, Heebeom Koo ${ }^{2,3^{*+}}$, Mi-La Cho ${ }^{1,2,3,5^{*}+}$ (D) and Sung-Hwan Park ${ }^{1,4^{*+}+}$

\begin{abstract}
Background: Rheumatoid arthritis (RA) is a progressive systemic autoimmune disease that is characterized by infiltration of inflammatory cells into the hyperplastic synovial tissue, resulting in subsequent destruction of adjacent articular cartilage and bone. Methotrexate (MTX), the first conventional disease-modifying antirheumatic drug (DMARD), could alleviate articular damage in RA and is implicated in humoral and cellular immune responses. However, MTX has several side effects, so efficient delivery of low-dose MTX is important.

Methods: To investigate the efficacy of MTX-loaded nanoparticles (MTX-NPs) against experimental model of RA, free MTX or MTX-NPs were administered as subcutaneous route to mice with collagen-induced arthritis (CIA) at 3 weeks after Cll immunization. The levels of inflammatory factors in tissues were determined by immunohistochemistry, confocal microscopy, real-time PCR, and flow cytometry.

Results: MTX-NPs ameliorated arthritic severity and joint destruction in collagen-induced arthritis (CIA) mice compared to free MTX-treated CIA mice. The levels of inflammatory cytokines, including interleukin (IL)-1 $\beta$, tumor necrosis factor-a, and vascular endothelial growth factor, were reduced in MTX-NPs-treated mice. Number of CD4 + IL-17 + cells decreased whereas the number of CD4 + CD25 + Foxp3 + cells increased in spleens from MTXNPs-treated CIA mice compared to MTX-treated CIA mice. The frequency of CD19+CD25 + Foxp3 + regulatory B cells increased in ex vivo splenocytes from MTX-loaded NPs-treated CIA mice compared to MTX-treated CIA mice.
\end{abstract}

\footnotetext{
*Correspondence: hbkoo@catholic.ac.kr; iammila@catholic.ac.kr; rapark@catholic.ac.kr

${ }^{\dagger}$ Jin-Sil Park and Donghyun Lee contributed equally to this work

${ }^{\dagger}$ Heebeom Koo, Mi-La Cho, and Sung-Hwan Park contributed equally to this work

${ }^{1}$ The Rheumatism Research Center, Catholic Research Institute of Medical Science, College of Medicine, The Catholic University of Korea, 222,

Banpo-daero, Seocho-gu, Seoul 06591, Republic of Korea

2 Department of Medical Life Sciences, College of Medicine, The Catholic

University of Korea, 222 Banpo-daero, Seocho-gu, Seoul 06591, Republic of Korea

Full list of author information is available at the end of the article
}

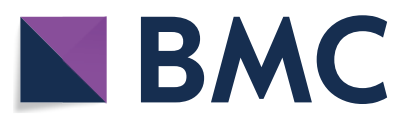

(c) The Author(s) 2022. Open Access This article is licensed under a Creative Commons Attribution 4.0 International License, which permits use, sharing, adaptation, distribution and reproduction in any medium or format, as long as you give appropriate credit to the original author(s) and the source, provide a link to the Creative Commons licence, and indicate if changes were made. The images or other third party material in this article are included in the article's Creative Commons licence, unless indicated otherwise in a credit line to the material. If material is not included in the article's Creative Commons licence and your intended use is not permitted by statutory regulation or exceeds the permitted use, you will need to obtain permission directly from the copyright holder. To view a copy of this licence, visit http://creativecommons.org/licenses/by/4.0/. The Creative Commons Public Domain Dedication waiver (http://creativeco mmons.org/publicdomain/zero/1.0/) applies to the data made available in this article, unless otherwise stated in a credit line to the data. 
Conclusion: The results suggest that MTX-loaded NPs have therapeutic potential for RA.

Keywords: Rheumatoid arthritis, Nanoparticles, Methotrexate, Interleukin-17-producing T cells, Regulatory B cells

\section{Background}

Rheumatoid arthritis (RA) is a progressive autoimmune disease characterized by synovial inflammation, hyperplasia, and formation of rheumatoid pannus, resulting in destruction of the adjacent articular cartilage and bone structure. The development of RA involves a complex interplay between immune cells and inflammatory mediators including inflammatory cytokines, proteolytic enzymes, and prostanoids [1-3]. Although the causes of $\mathrm{RA}$ are unclear, infiltration of $\mathrm{T}$ and $\mathrm{B}$ cells into the joints leads to induction of inflammatory cytokines, such as tumor necrosis factor (TNF)- $\alpha$, interleukin (IL)-6, IL-1 $\beta$, and IL-17A and autoantibodies and drives the proliferation of fibroblast-like synoviocytes and destruction of bone $[3,4]$.

IL-17-producing $\mathrm{T}$ helper (Th17) cells, which produce IL-17A, IL-17F, IL-21, and TNF- $\alpha$, are involved in the pathogenesis of various autoimmune diseases, including RA, multiple sclerosis, and psoriasis [5, 6]. IL-6 drives the differentiation of naïve $\mathrm{T}$ cells into Th17 cells by activating STAT3, a key transcription factor for Th17 cells $[7,8]$. In RA synovium, IL-17-producing cells were observed in the $\mathrm{T}$ cell-rich area and IL-17 contributes to increased production of IL-6 and leukemia inhibitory factor. Moreover, it has synergistic effects with IL- $1 \beta$ or TNF- $\alpha$ on inflammation [9-11]. Rheumatoid synovial tissue contains abundant B cells, which secrete proinflammatory mediators and autoantibodies, including rheumatoid factor and anti-citrullinated protein antibodies [3, 12]. Moreover, B cells act as antigen-presenting cells for autoreactive $\mathrm{T}$ cells [13].

Methotrexate (MTX) is a first-line disease-modifying antirheumatic drug (DMARD) that alleviates articular damage in RA [14]. It is an antifolate metabolite that inhibits folate-dependent enzymes in the de novo synthesis of purines and pyrimidines [15, 16]. MTX is used as monotherapy for patients with early RA [17] and as an anchor drug for combination therapy with other DMARDs or biologics in patients with established RA who are MTX-insufficient responders [18]. However, long-term use of MTX leads to drug resistance and causes severe side effects such as nausea, neutropenia, pulmonary fibrosis, and hepatitis $[15,19]$.

Nanoparticles (NPs) are promising therapeutics due to their ability to deliver and release drugs [20,21]. Multiple NPs have been developed for drug delivery in various diseases. They can inhibit fast excretion of drug from body by sustained release. NPs are typically administered by intravenous injection, oral feeding, or subcutaneous injection. Intravenously injected NPs are rapidly effective but also rapidly excreted and have a high risk of side effects. Oral feeding is the easiest and low risk, but the absorption rate is too low. Subcutaneous injection shows moderate effectiveness in relation to these methods, so has an advantage in occupying the middle ground. However, most NP studies for RA therapy have used intravenous injection and oral feeding.

MTX-loaded nanoparticles (MTX-NPs) ameliorated murine model of experimental arthritis after subcutaneous injection. They were formulated with hydrophobic poly (D, L lactide-co-glycolide) (PLGA) and amphiphilic polyvinyl alcohol (PVA). MTX was stably loaded into the NPs. MTX-NPs attenuated the severity of murine model of experimental arthritis and reciprocally regulated Th17 and regulatory $\mathrm{T}$ and $\mathrm{B}$ cells in vivo.

\section{Methods \\ Materials}

Resomer RG 502 H PLGA and PVA (MW 30,000-70,000) were purchased from Sigma Aldrich (St. Louis, MO, USA). Dimethyl sulfoxide, 99.0\% (methyl sulfoxide, DMSO) was purchased from Samchun (Seoul, Gangnamgu, Korea).

\section{Preparation and characterization of MTX loaded nanoparticles}

PLGA (50 mg) and methotrexate (5 mg) were dissolved in DMSO at $60{ }^{\circ} \mathrm{C}$. The solution was added dropwise to an aqueous solution of $1 \%$ PVA (w/v). The solution was homogenized at 7000 RPM for 2 min using a homogenizer (Ultra Turrax ${ }^{\circledR}$ T-25 homogenizer; IKA ${ }^{\circledR}$-Werke, Staufen, Germany). After homogenization, non-encapsulated substances were removed by dialysis in distilled water for $1 \mathrm{~h}$ through a 14,000 molecular weight cut-off membrane. The size distribution of MTX-NP was measured in PBS using a Zetasizer Nano ZS90 (Malvern Instruments, Malvern, UK) at $25^{\circ} \mathrm{C}$. Encapsulated MTX was quantified by assaying the absorbance of MTX at $370 \mathrm{~nm}$ and encapsulation efficiency was calculated by the formula: ((amount of encapsulated drug/amount of added drug) $\times 100 \%$ ). MTX-NP was placed in a dialysis bag and immersed in a container containing $50 \mathrm{~mL}$ of PBS to analyze the drug release profile. At predetermined time points, $200 \mu \mathrm{L}$ of external PBS were removed and the absorbance at $370 \mathrm{~nm}$ of MTX was measured using Microplate Reader Synergy H1 (Bio-Tek, USA). 


\section{Toxicological analysis}

Mice were injected subcutaneously with vehicle, free MTX $(2.5 \mathrm{mg} / \mathrm{kg})$ or MTX-loaded nanoparticle $(2.5 \mathrm{mg} /$ $\mathrm{kg}$ based on MTX). Twenty-four hours post-injection, blood samples were collected from the heart of mice under respiratory anesthesia. The blood sample for complete blood count $(\mathrm{CBC})$ was placed in EDTA tube and CBC was measured using HEMAVET 950FS blood cell counter (Drew Scientific, Inc., Dallas, TX, USA). The blood samples for blood chemistry analysis were placed in heparin tubes and plasma were isolated. Creatinine aspartate aminotransferase (AST) and alanine aminotransferase (ALT) in plasma were measured by Fuji Dri-Chem NX500 (Fujifilm Corporation, Tokyo, Japan).

\section{$\mathrm{CIA}$ induction and treatment with nanoparticles}

Six-week-old male DBA/1 J mice were purchased from Orient Bio Inc. (Seongnam, Korea). CIA was induced as described previously [22]. To induce CIA in mice, CII was dissolved overnight in $0.1 \mathrm{~N}$ acetic acid $(4 \mathrm{mg} / \mathrm{mL})$ with gentle rotation at $4{ }^{\circ} \mathrm{C}$. DBA/ $1 \mathrm{~J}$ mice were injected intradermally at the base of the tail with $100 \mu \mathrm{g}$ of CII emulsified in Freund's adjuvant (Chondrex). Two weeks later, $100 \mu \mathrm{g}$ of type II collagen dissolved and emulsified 1:1 with incomplete Freund's adjuvant (Difco) was administered to the hind leg of mice as a booster injection. On day 24 after the first immunization, mice were injected subcutaneously with $2.5 \mathrm{mg} / \mathrm{kg}$ MTX or MTXNPs twice weekly. Animals were maintained under specific pathogen-free conditions at the Institute of Medical Science of the Catholic University of Korea and were fed standard mouse chow and water. All experimental procedures were examined and approved by the Animal Research Ethics Committee of the Catholic University of Korea; the procedure conformed to all National Institutes of Health of the United States guidelines (Permit number: 2020-0067-01).

\section{Clinical assessment of arthritis}

To assess the severity of joint inflammation, the arthritis index was scored twice weekly from the onset of arthritis for up to 8-10 weeks after the primary immunization. The severity of arthritis was assessed on a scale of $0-4$ according to the following criteria, as described previously [23]: $0=$ no edema or swelling, $1=$ slight edema and erythema limited to the foot or ankle, $2=$ slight edema and erythema from the ankle to the tarsal bone, $3=$ moderate edema and erythema from the ankle to the tarsal bone, and $4=$ edema and erythema from the ankle to the entire leg. The arthritic score for each mouse was expressed as the sum of the scores of four limbs. Incidence was calculated as 25 percent of the presence of arthritis symptoms in one foot.

\section{Antibodies}

The following antibodies were used for immunohistochemistry: rabbit polyclonal anti-TNF- $\alpha$ (\#ab6671) and rabbit polyclonal anti-vascular endothelial growth factor (VEGF) (EP1176Y, \#ab52917) antibodies were from abcam; rabbit polyclonal anti-IL-1 $\beta$ (\#NB600-633) antibody was from Novus Biologicals. The following antibodies were used for flow cytometry: rat monoclonal APC anti-CD45R (B220) (RA3-6B2, \#17-0452-83), mouse monoclonal PE anti-CD95 (APO-1/Fas) (15A7, \#12-0951-81), mouse monoclonal PerCP-Cyanine5.5 anti-CD19 (SJ25C1, \#45-0198-42), rat monoclonal FITC anti-CD5 (53-7.3, \#11-0051-82), rat monoclonal PE antiCD1d (1B1, \#12-0011-82), rat monoclonal APC antiIL-10 (JES5-16E3, \#17-7101-82) antibodies were from Thermo Fisher Scientific; rat monoclonal PE-Cy ${ }^{\mathrm{TM}} 7$ antiCD19 (ID3, \#552854) antibody was from BD Biosciences; Alexa Fluor ${ }^{\circledR} 488$ anti-GL7 (GL7, \# 144612) antibodies was from BioLegend. The following antibodies were used for confocal microscopy: rat monoclonal Alexa Fluor ${ }^{\circledR}$ 488 anti-CD4 (GK1.5, \#100423) and rat monoclonal APC anti-CD25 (PC6, \#102012) antibodies were from BioLegend; rat monoclonal PE anti-IL-17A (eBio17B7, \#127177-81) antibody was from Thermo Fisher Scientific; mouse monoclonal PE anti-STAT3 (pY705) (4/P-STAT3, \#612569) antibody was from BD Bioscience; rabbit polyclonal PE anti-Foxp3 antibody (\#NP100-39002) antibody was from Novus Biologicals.

\section{Histology}

Mouse joint tissues were fixed in 10\% neutral-buffered formalin, decalcified in a decalcifying agent (National Diagnostics, Atlanta, GA, USA), embedded in paraffin, and sectioned. The sections $(5 \mu \mathrm{m}$ thick) were stained with hematoxylin and eosin (H\&E) and scored as described previously [24]. Inflammation was scored using the following criteria: 0 , no inflammation; 1 , slight thickening of the lining or infiltration of some cells into the underlying layer; 2, slight thickening of the lining with infiltration of some cells into the underlying layer; 3 , thickening of the lining, with an influx of cells into the underlying layer and cells evident in the synovial space; and 4, extensive infiltration of the synovium by inflammatory cells. Cartilage damage was evaluated by staining with Safranin O and toluidine blue, and the extent of damage was scored using the following criteria: 0 , no destruction; 1 , minimal erosion (limited to single spots); 2 , slight-to-moderate erosion in a limited area; 3 , more extensive erosion; and 4, general destruction.

\section{Immunohistochemistry}

Sections were treated with $3 \%(\mathrm{v} / \mathrm{v}) \mathrm{H}_{2} \mathrm{O}_{2}$ in methanol to block endogenous peroxidase activity. 
Immunohistochemistry was performed using the Envision Detection ${ }^{\mathrm{TM}}$ kit (DAKO Agilent Technologies Inc., Santa Clara, CA, USA). Tissue sections were incubated with primary antibodies against IL-1 $\beta$, TNF- $\alpha$, and VEGF for $2 \mathrm{~h}$ at room temperature. Sections were then incubated with a biotinylated secondary antibody and streptavidin-peroxidase complex for $30 \mathrm{~min}$. The final colored products were developed using chromogen diaminobenzidine. The sections were examined by light microscopy (Olympus, Tokyo, Japan). The number of positive cells was counted at high-power field (magnifications $\times 400$ ) with the aid of Adobe Photoshop software by four individuals and averaged three randomly selected fields per tissue section.

\section{Isolation of splenocytes}

Mouse spleens were ground using sterilized glass slides with frosted ends and red blood cells were lysed in hypotonic ACK buffer $\left(0.15 \mathrm{mM} \mathrm{NH}_{4} \mathrm{Cl}, 1 \mathrm{mM} \mathrm{KCO}\right.$, and $0.1 \mathrm{mM}$ EDTA, pH 7.4). The remaining splenocytes were filtered through a $40 \mu \mathrm{m}$ cell strainer (Falcon, Durham, NC) and maintained in RPMI 1640 medium containing $5 \%$ fetal bovine serum (ThermoFisher Scientific, MA, USA).

\section{Flow cytometry}

For surface marker staining, single-cell suspensions were washed with FACS buffer and incubated with fluorochrome labeled-antibodies for $30 \mathrm{~min}$ at $4{ }^{\circ} \mathrm{C}$. For intracellular staining, single-cell suspensions were cultured with $25 \mathrm{ng} / \mathrm{ml}$ phorbol 12-myristate 13-acetate (SigmaAldrich, St. Louis, MO, USA) and $250 \mathrm{ng} / \mathrm{ml}$ ionomycin (Sigma-Aldrich) with the addition of GolgiStop (BD Biosciences, Franklin Lakes, NJ, USA) for $4 \mathrm{~h}$. After surface staining, cells were fixed and permeabilized with Cytofix/Cytoperm according to the manufacturer's instructions (BD Biosciences). After washing with Perm/Wash buffer, antibodies for intracellular staining were added for $30 \mathrm{~min}$ at $4{ }^{\circ} \mathrm{C}$. To determine the frequency of germinal center (GC) B cells, splenocytes were immunostained with Alexa Fluor $^{\circledR}$ 488-conjugated anti-GL7 PE-conjugated anti-Fas, APC-conjugated anti-B220, and PerCPCyanine5.5 anti-CD19 antibodies. For regulatory B cells, splenocytes were immunostained with $\mathrm{PE}-\mathrm{Cy}^{\mathrm{TM}} 7$ antiCD19, rat monoclonal FITC anti-CD5, PE anti-CD1d, and APC anti-IL-10 antibodies. Events were collected using the FACS Calibur (BD Biosciences) or CytoFLEX (Beckman Coulter), and the data were analyzed using Flow Jo software, v. 7.6 (Treestar, Ashland, OR, USA).

\section{Confocal microscopy}

Spleen tissues were snap-frozen in liquid nitrogen and stored at $-70{ }^{\circ} \mathrm{C}$. Tissue Sects. $(5 \mu \mathrm{m}$ thick $)$ were fixed in acetone. To stain IL-17+or phosphorylated (p)-STAT3+in CD4+cells, Alexa Fluor ${ }^{\circledR}$ 488-labeled anti-CD4, PE-labeled anti-IL-17A, and PE-labeled antip-STAT3 (pTyr705) antibodies were used. To stain regulatory $\mathrm{T}$ (Treg) cells, Alexa Fluor ${ }^{\circledR} 488$-labeled anti-CD4, PE-labeled anti-Foxp3, and APC-labeled anti-CD25 antibodies were used. Sections were analyzed using the LSM 510 Meta Confocal Microscopy System (Carl Zeiss, Oberkochen, Germany). Positive cells were counted visually at high magnification by four investigators.

\section{Real-time polymerase chain reaction}

Total RNA was extracted using TRI Reagent (Molecular Research Center, Inc., Cincinnati, OH, USA), and cDNA was synthesized with the Dyne First-Strand cDNA Synthesis Kit (Dyne Bio, Seongnam, Korea) according to the manufacturer's protocol. Gene expression was measured using the StepOnePlus Real-Time PCR System (Applied Biosystems, Foster City, USA) with SYBR premix (Bioline USA Inc. Taunton, MA). The following primers were used: IL-1 $\beta, \quad 5^{\prime}$-GGATGAGGACATGAGCACATTC- ${ }^{\prime}$ (sense) and 5'-GGAAGACAGGCTTGTGCTCTGA$3^{\prime}$ (antisense); IL-6, 5'-AACGATGATGCACTTGCA GAAA- $3^{\prime}$ (sense) and $5^{\prime}$-TCTGAAGGACTCTGGCTT TGTC-3' (antisense); IL-17A, 5'-TTTAACTCCCTT GGCGCAAAA- $3^{\prime}$ (sense) and 5'-CTTTCCCTCCGC ATTGACAC-3' (antisense); and $\beta$-actin, $5^{\prime}$-GTACGA CCAGAGGCATACAGG-3' (sense) and $5^{\prime}$-GATGAC GATATCGCTGCGCTG- $3^{\prime}$ (antisense). mRNA levels were normalized to that of $\beta$-actin mRNA.

\section{Statistical analysis}

All statistical analyses were performed using Prism (v. 8 for Windows; GraphPad Software). P-values were calculated by two-tailed paired $t$-test and two-way analysis of variance (grouped). $\mathrm{P}<0.05$ was considered indicative of statistical significance.

\section{Results}

\section{Preparation and characterization of MTX-NPs}

We prepared PLGA NPs via a homogenization method using PVA as stabilizer. MTX was physically loaded into the NPs (Fig. 1a). MTX was stably encapsulated in a hydrophobic core (PLGA) with an encapsulation efficiency of $76.6 \pm 4.9 \%$. The size of MTX-NPs was $227.2 \pm 1 \mathrm{~nm}$ and MTX-NPs were spherical by transmission electron microscopy (TEM) (Fig. 1b). The size is suitable for injection into body by syringes with small needle. The polydispersity index (PdI) and zeta potential of MTX-NP were $0.139 \pm 0.041$ and $-2.8 \pm 0.02$, respectively, showing a homogeneous formulation without aggregation and near-neutral surface, respectively. In PBS at $\mathrm{pH} 7.4$, free MTX was slowly released from the 

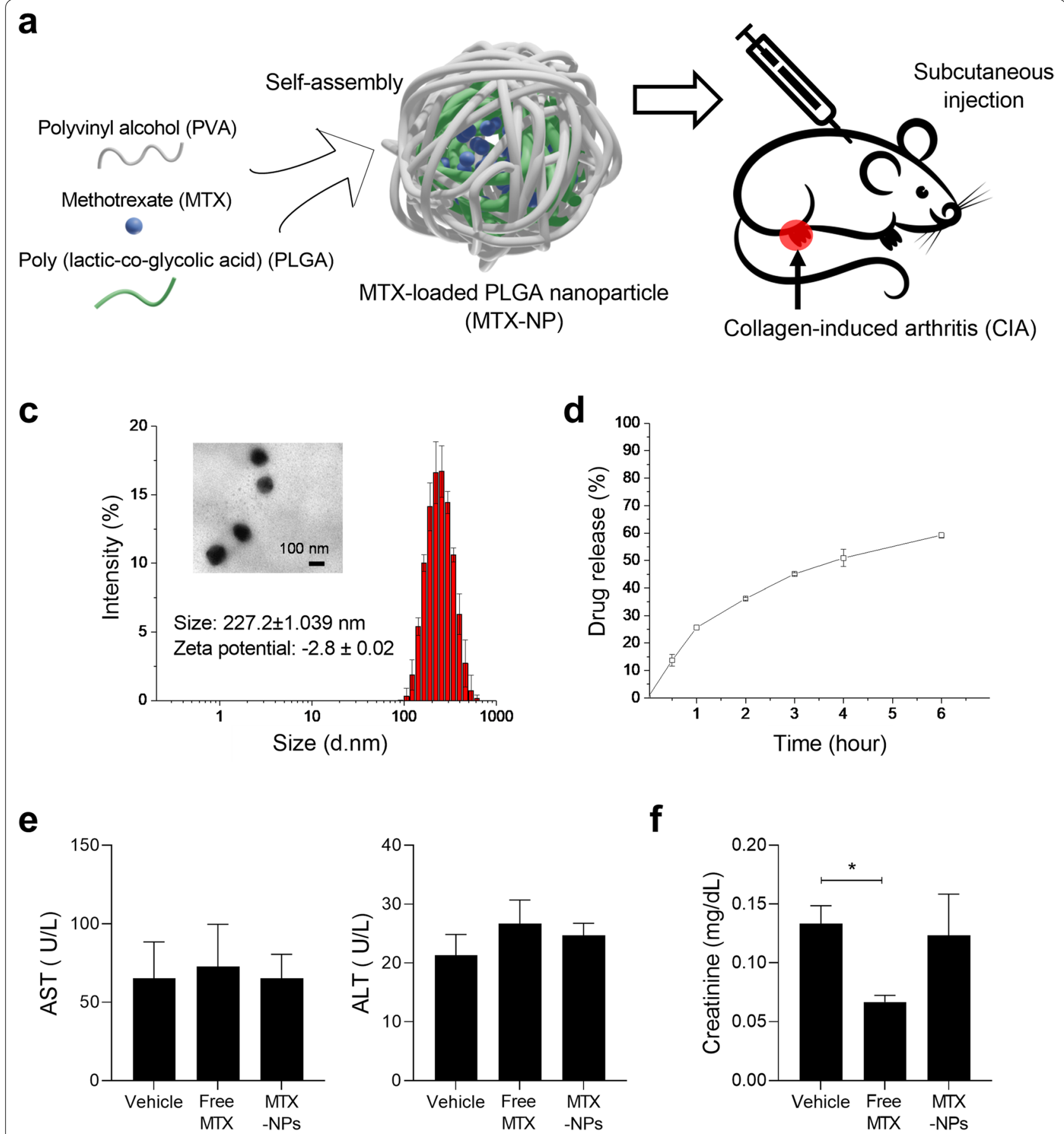

Fig. 1 Characteristics of MTX-NPs. a Schematic of MTX-NP synthesis. b Size distribution, zeta-potential value, and TEM image of MTX-loaded nanoparticles. c MTX release profile of MTX-NPs. d Toxicological analysis of MTX-NPs in plasma. Plasma level of hepatotoxicity biomarker, aspartate aminotransferase (AST) and alanine aminotransferase (ALT). e Creatinine concentration, biomarker for kidney function. Error bar represents mean \pm S.D. $(n=3) .{ }^{* *} P<0.01$ vs. control group

PLGA core (Fig. 1c), indicating sustained release (Fig 1d). To investigate side effect of MTX-loaded nanoparticle, we measured complete blood count $(\mathrm{CBC})$, creatinine, aspartate aminotransferase (AST) and alanine
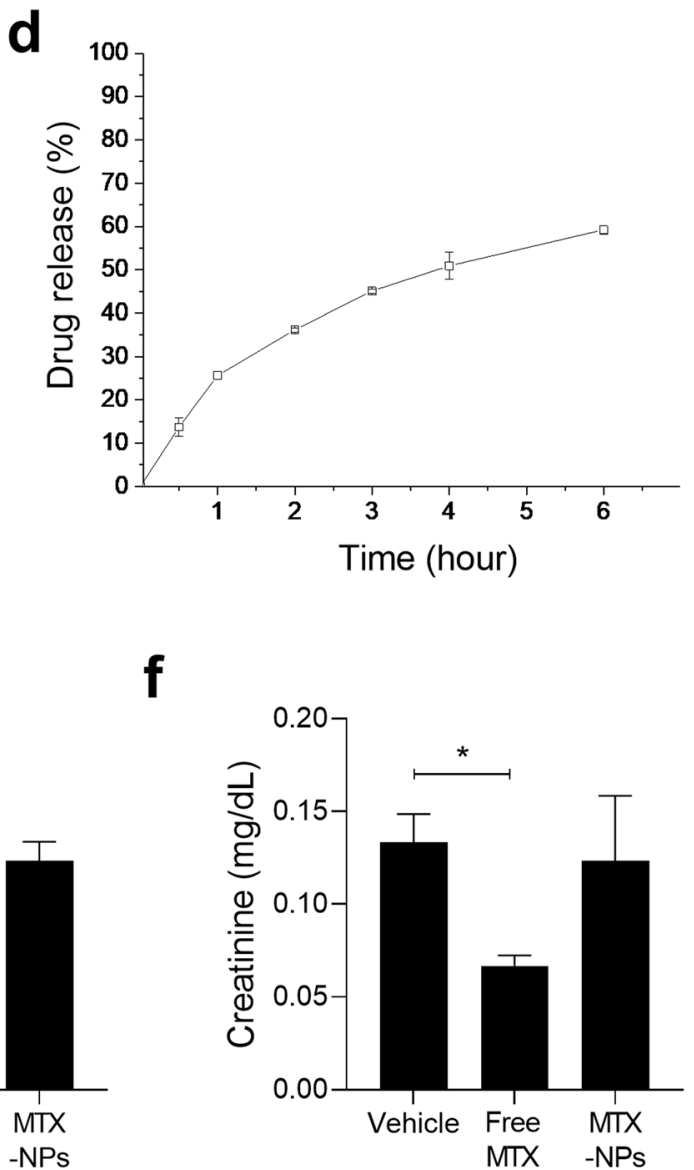

f 
Table 1 Complete blood count of mice which were subcutaneously injected with vehicle, free MTX or MTX NPS

\begin{tabular}{|c|c|c|c|c|}
\hline & $\begin{array}{l}\text { Normal } \\
\text { range }\end{array}$ & Vehicle & Free MTX & MTX NPs \\
\hline WBC $(K / \mu L)$ & $1.8-10.7$ & $4.38 \pm 1.81$ & $5.27 \pm 0.39$ & $4.65 \pm 1.59$ \\
\hline$N E(K / \mu L)$ & $0.1-2.4$ & $0.47 \pm 0.23$ & $0.79 \pm 0.07$ & $0.62 \pm 0.06$ \\
\hline $\mathrm{LY}(\mathrm{K} / \mu \mathrm{L})$ & $0.9-9.3$ & $3.72 \pm 1.47$ & $4.29 \pm 0.37$ & $3.79 \pm 1.4$ \\
\hline $\mathrm{MO}(\mathrm{K} / \mu \mathrm{L})$ & $0.0-0.4$ & $0.16 \pm 0.09$ & $0.16 \pm 0.02$ & $0.22 \pm 0.14$ \\
\hline $\mathrm{EO}(\mathrm{K} / \mu \mathrm{L})$ & $0.0-0.2$ & $0.023 \pm 0.015$ & $0.017 \pm 0.006$ & $0.017 \pm 0.015$ \\
\hline $\mathrm{BA}(\mathrm{K} / \mu \mathrm{L})$ & $0.0-0.2$ & $0.003 \pm 0.006$ & $0 \pm 0$ & $0.003 \pm 0.006$ \\
\hline NE (\%) & $6.6-38.9$ & $10.51 \pm 0.82$ & $15.12 \pm 0.73$ & $14.03 \pm 3.49$ \\
\hline LY (\%) & $55.8-91.6$ & $85.37 \pm 1.71$ & $81.39 \pm 1.09$ & $81.01 \pm 3.37$ \\
\hline MO (\%) & $0.0-7.5$ & $3.55 \pm 0.7$ & $3.14 \pm 0.73$ & $4.55 \pm 1.67$ \\
\hline EO (\%) & $0.0-3.9$ & $0.48 \pm 0.23$ & $0.3 \pm 0.07$ & $0.34 \pm 0.21$ \\
\hline BA (\%) & $0.0-2.0$ & $0.08 \pm 0.02$ & $0.63 \pm 0.01$ & $0.077 \pm 0.09$ \\
\hline $\mathrm{RBC}(\mathrm{M} / \mu \mathrm{L})$ & $6.36-9.42$ & $7.47 \pm 0.57$ & $7.67 \pm 0.7$ & $7.21 \pm 0.33$ \\
\hline $\mathrm{Hb}(\mathrm{g} / \mathrm{dL})$ & $11.0-15.1$ & $12.17 \pm 0.64$ & $12.2 \pm 0.89$ & $12.17 \pm 0.65$ \\
\hline PLT $(K / \mu L)$ & $592-2972$ & $776 \pm 307$ & $757.3 \pm 223$ & $792.7 \pm 87.51$ \\
\hline MPV (fL) & $5.0-20.0$ & $3.73 \pm 0.06$ & $3.77 \pm 0.06$ & $3.8 \pm 0.17$ \\
\hline
\end{tabular}

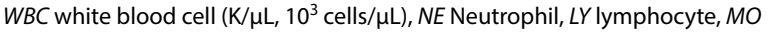
monocyte, EO eosinophil, $B A$ basophil, $R B C$ red blood cell (M/ $\left.\mu \mathrm{L}, 10^{6} \mathrm{cell} / \mathrm{s} / \mathrm{LL}\right), \mathrm{Hb}$ hemoglobin, PLT platelet, MPV mean platelet volume (mean \pm S.D., $\mathrm{n}=3$ )

However, in case of MTX-loaded NPs, the value was similar with that of control group, which means that NPs are useful for reducing renal toxicity of MTX (Fig. 1f).

\section{MTX-NPs attenuate the severity of autoimmune arthritis}

To determine whether MTX-NPs could modulate the development of experimental model of arthritis in vivo, free MTX or MTX-NPs were administered to mice with CIA at 3 weeks after CII immunization (Fig. 2a). Subcutaneous injection of MTX-NPs in arthritic mice significantly reduced the arthritis score and incidence compared with vehicle-treated CIA mice. Injection of free MTX also reduced the arthritis score and incidence in CIA mice, but statistical significance was not consistently achieved (Fig. 2b). Histologic examination of joints stained with $\mathrm{H} \& \mathrm{E}$ showed that the ankles of MTX-NPs-treated mice exhibited less severe inflammation, bone damage, and cartilage damage compared with vehicle-treated mice. Application of MTX-NPs, in particular, exerted a more profound inhibitory effect on joint destruction compared with free MTX (Fig. 2c). Furthermore, the levels of inflammatory mediatorsincluding IL- $1 \beta$, TNF- $\alpha$, and VEGF-were significantly lower in the joint sections from MTX-NPs-treated mice compared with vehicle-treated mice (Fig. 3).

\section{MTX-NPs reciprocally regulate the Th 17 cells and Treg cells in vivo}

To evaluate whether MTX-NPs suppress Th17 cells in vivo, the number of CD4+IL-17+Th17 cells in the spleens from CIA mice injected with MTX-NPs was investigated by confocal microscopy. The number of Th17 cells was lower in MTX-NPs- or free MTXtreated CIA mice compared with vehicle-treated CIA mice (Fig. 4a). STAT3 phosphorylation in CD4+ cells decreased in MTX-NPs- or free MTX-treated CIA mice compared to vehicle-treated CIA mice, but there was no statistical significance (Fig. 4b). To investigate whether MTX-NPs reciprocally regulate the population of Th17 and Treg cells in vivo, the number of CD4+CD25+Foxp3+Treg cells in the spleen was investigated. The number of Treg cells in the spleen of MTX-NPs-injected mice significantly increased compared to vehicle-injected mice, and the increase was also significant compared with free MTX-injected mice (Fig. 4c). In addition, the mRNA levels of IL-6 and IL$17 \mathrm{~A}$, inflammatory cytokines related to Th17 cell development, significantly decreased in ex vivo splenocytes of mice injected with MTX-NPs compared to mice injected with vehicle (Fig. 4d).

\section{MTX-NPs increase regulatory B cells in vivo}

To evaluate whether MTX-NPs act on B-cell responses in vivo, we examined the number of ex vivo CD19+B220+GL-7 + Fas + GC B cells and $\mathrm{CD} 19+\mathrm{CD} 5+\mathrm{CD} 1 \mathrm{~d}+\mathrm{IL}-10+$ regulatory B (Breg) cells in splenocytes from CIA mice injected with MTXNPs by flow cytometry. The number of GC B cells was lower whereas the number of regulatory B cells was higher in ex vivo splenocytes from MTX-NPs-injected CIA mice compared with vehicle-injected mice, but there was no statistical significance (Fig. 5).

\section{(See figure on next page.)}

Fig. 2 MTX-NPs ameliorated the severity of collagen-induced arthritis. a A graphic scheme of CIA induction and vehicle, free MTX or MTX-NPS administration. Beginning 3 weeks after the first immunization with type II collagen (CII), mice were injected subcutaneously with vehicle, free MTX, or MTX-NPs twice per week for 7 weeks ( $n=5 /$ group). b Arthritis score and incidence are shown for each group. $\mathbf{c}$ At 70 days after the first Cll immunization, tissue sections from the paw and ankle joints of mice were stained with hematoxylin and eosin (original magnification $\times 40$ ). Lower panels show enlarged view of the region within a box in the upper panels in each group. Asterisk: inflammatory cell infiltration. Representative histological features are shown. Graphs present quantified levels of inflammation, bone damage, and cartilage damage. Values are means \pm SEM. *, $P<0.05,{ }^{* *}, P<0.01$, and ${ }^{* *}, P<0.001$ vs. control group. Data are representative of two independent experiments 
a

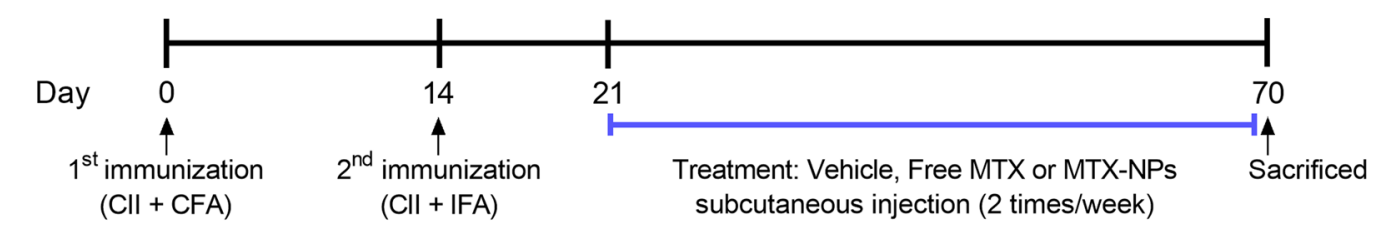

b
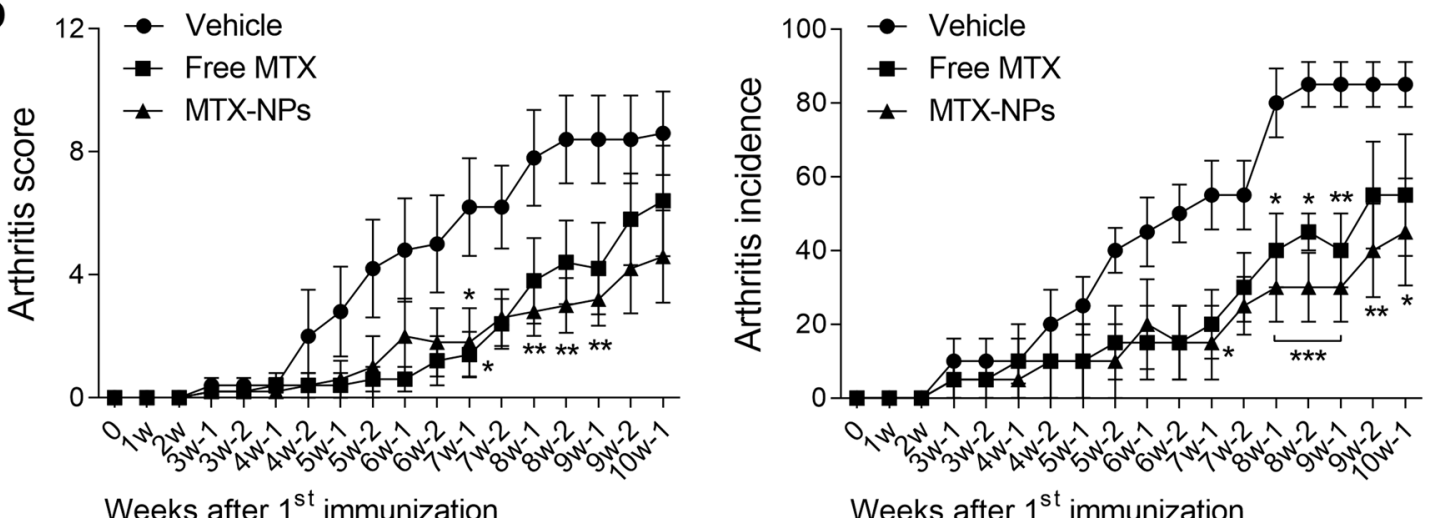

C
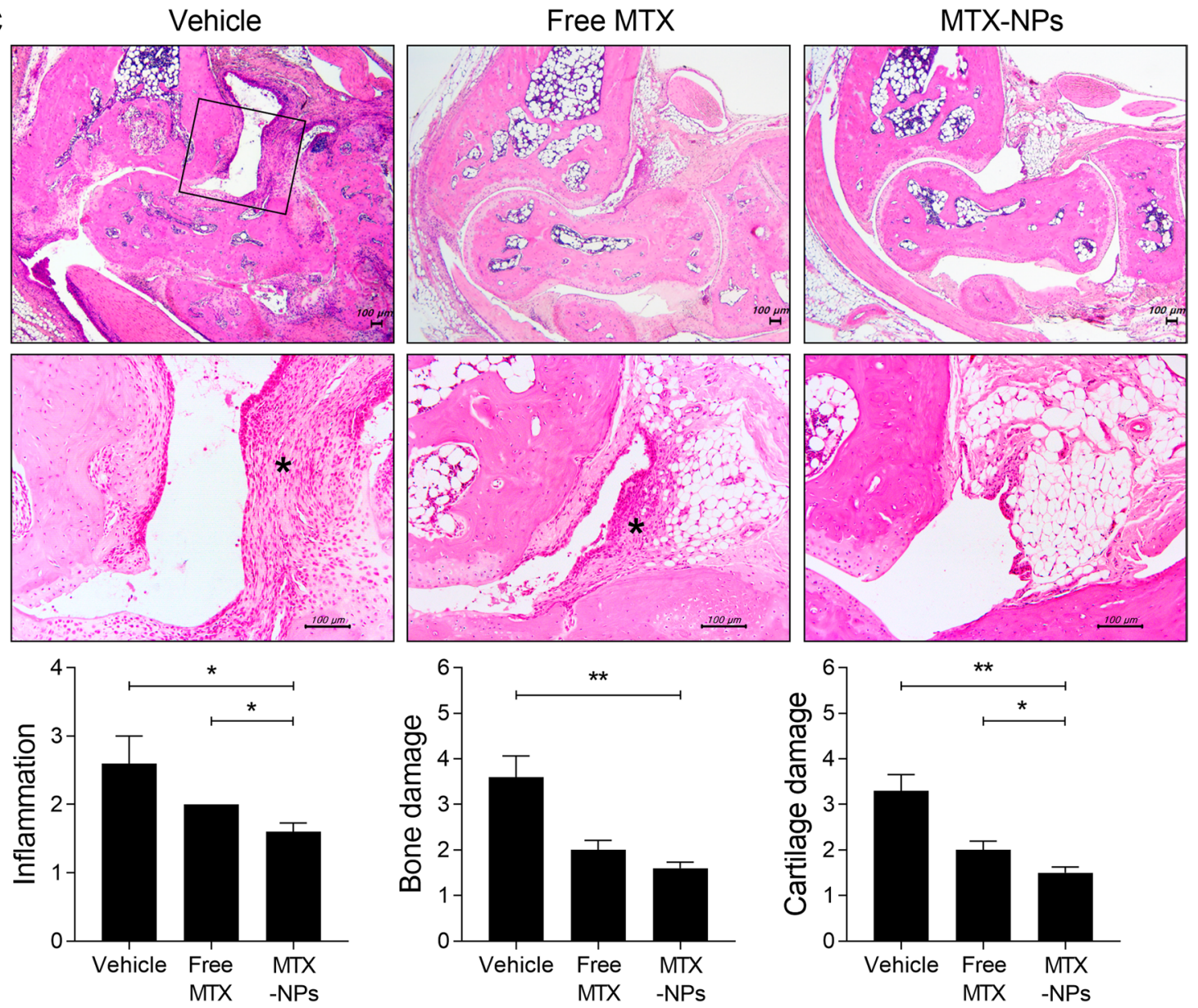

Fig. 2 (See legend on previous page.) 

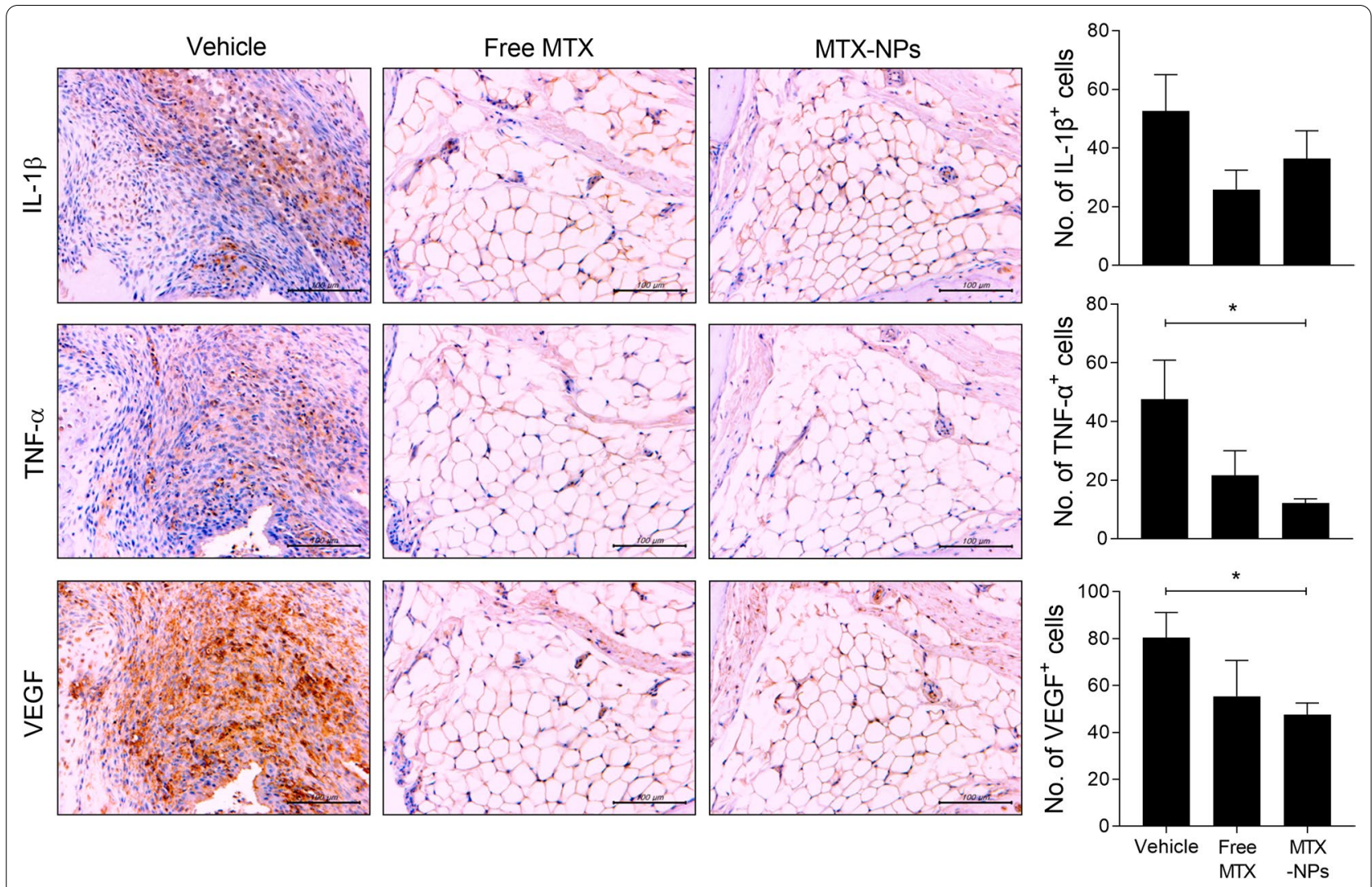

Fig. 3 MTX-NPs suppressed the levels of inflammatory mediators in vivo. Beginning 3 weeks after the first immunization with type II collagen (CII), mice were injected subcutaneously with vehicle, free MTX, or MTX-NPs twice per week for 7 weeks ( $n=5 / g r o u p)$. At 70 days after the first immunization with Cll, sections of joint tissues ( $n=5 /$ group) were stained with antibodies against interleukin (IL)- $1 \beta$, tumor necrosis factor (TNF)- $a$, and VEGF. Graphs present numbers of antibody-positive cells for each cytokine. Data are means \pm SEM of two independent experiments. ${ }^{*} P<0.05$ vs. control group

\section{Discussion}

We investigated the therapeutic potential of MTX-NPs administered subcutaneously in a murine model of autoimmune arthritis. MTX-NPs significantly reduced the clinical and histologic severity of experimental model of arthritis. MTX-NPs reduced the number of TNF- $\alpha-$ and VEGF-positive cells and reciprocally regulated the number of Th17 and Treg cells in the spleen from MTXNP-treated CIA mice. Moreover, injection of MTX-NPs showed a tendency to increase the number of regulatory $B$ cells in ex vivo splenocytes of CIA mice.

Synovial inflammation in RA involves infiltration of inflammatory cells, including monocytes/macrophages, $\mathrm{B}$ cells, and $\mathrm{T}$ cells, which are sources of chemokines and inflammatory cytokines [25]. $\mathrm{T}$ cells are a key player in the inflamed joints of patients with RA [26]. Although most subsets of CD4+ T cells are involved in RA pathogenesis, Th17 cells in particular positively correlate with disease activity in RA [27]. In CIA mice, deficiency of IL-17 suppressed the development of arthritis and reduced the production of type II collagen-specific immunoglobulin [28]. Moreover, blockade of IL-17 ameliorated the severity of arthritis and prevented synovial inflammation and joint destruction in CIA mice [29]. MTX exerts a potent therapeutic effect by modulating humoral and cellular immune responses in RA management $[14,30]$. MTX increases the sensitivity of T cells to apoptosis [16] and inhibits NF- $\kappa B$ activation in T cells via tetrahydrobiopterin 4 depletion and JNK activation [31]. MTX suppresses the expression of IL-6 and IL-6-driven proliferation of fibroblast-like synoviocytes from patients with RA [32]. Thomas et al. demonstrated that MTX suppressed the JAK/STAT pathway in the Drosophila system and human macrophage lines [33], but the effect of MTX on JAK/STAT signaling and Th17 and Treg frequencies in the CIA model are unclear. The number of Th17 cells in the spleen of CIA mice decreased by injection of free MTX, and the effect was increased by injection of MTX-NPs.

The importance of B cells in RA pathogenesis has been demonstrated. B-cell-deficient mice had impaired CIA development [34], and B-cell depletion by an anti-CD20 

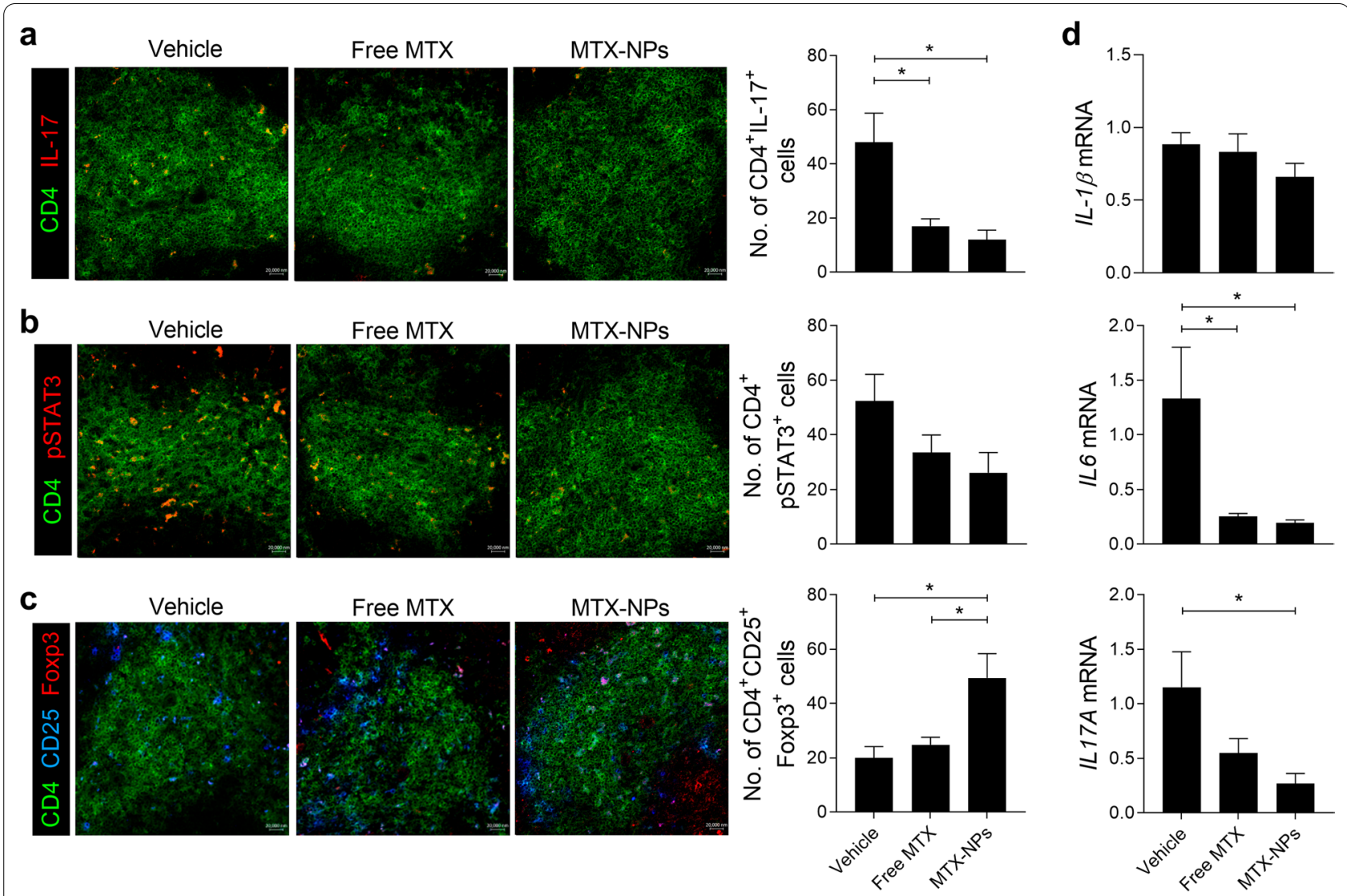

Fig. 4 MTX-NPs regulate the number of Th17/Treg cells and expression of inflammatory cytokines in vivo. Beginning 3 weeks after the first immunization with type II collagen (CII), mice were injected subcutaneously with vehicle, free MTX or MTX-NPs twice per week for 7 weeks ( $n=5$ / group). a-c At 70 days after the first immunization, spleen tissues were isolated and stained for CD4+IL-17+ (a), CD4 + p-STAT3 (Y705) + (b), and $\mathrm{CD} 4+\mathrm{CD} 25+$ Foxp3 + (c) cells. Cell subsets were analyzed in four independent quadrants by confocal laser microscopy. The distributions of the cell populations are shown. $\mathbf{d}$ At 70 days after the first immunization, ex vivo splenocytes were isolated and the mRNA levels of IL-6, IL-1 $\beta$, and IL-17 were determined by real-time PCR. Data are means \pm SEM of two independent experiments. ${ }^{*} P<0.05$ vs. control group
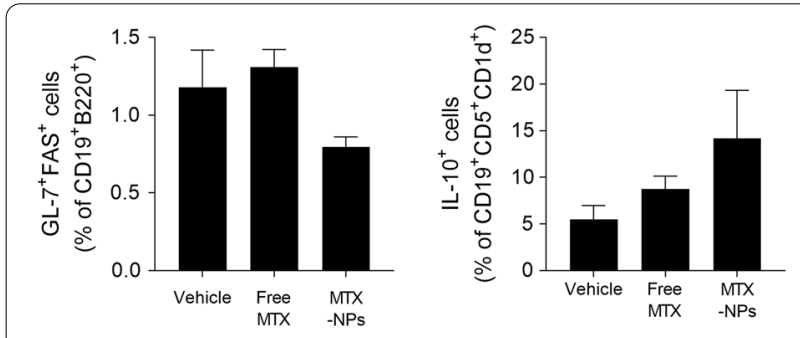

Fig. 5 MTX-NPs increased the number of regulatory B cells in vivo. Beginning 3 weeks after the first immunization with type II collagen (CII), mice were injected subcutaneously with vehicle, free MTX, or MTX-NPs twice per week for 7 weeks ( $n=3$ /group). At 70 days after the first immunization, ex vivo splenocytes were isolated and the number of CD19+B220+GL-7 + FAS + and CD19+CD25 + Foxp3 + cells determined by flow cytometry. Values are percentages of positive cells antibody delayed CIA development [35]. Immunization with type II collagen induced the formation of germinal centers in lymph nodes, which was necessary for CIA development [36]. Breg cells control autoimmune diseases by secreting anti-inflammatory cytokines (e.g., IL-10 and IL-35) and transforming growth factor- $\beta$ [37, 38]. Moreover, Breg cells suppress the differentiation of proinflammatory lymphocytes (e.g., Th1 and Th17 cells) and dendritic cells [39]. The frequency of Th17 cells and germinal center $\mathrm{B}$ cells decreased in ex vivo splenocytes of MTX-NP-treated CIA mice.

The elimination half-life of free MTX at the injection site in human is $0.16 \mathrm{~h}$ in case of subcutaneous injection [40]. Our NPs provided sustained release of MTX and increased the residence time. Although the release of MTX from NPs was faster than in prior reports, it affected the therapeutic results significantly. It is necessary to test and optimize further the release pattern of MTX by changing NP size or composition. In addition, 
MTX in NP could be taken up by T cells and B cells before release. This is because the NP surface was coated with PVA; we did not use polyethylene glycol groups to prevent fouling and unwanted uptake into immune cells. In addition, further modification with biological ligands will provide information for specific targeting of NPs to particular cell types.

\section{Conclusion}

In summary, our study showed a therapeutic efficacy of MTX-NPs in mice with CIA. Subcutaneous injection of MTX-NPs effectively alleviated the development of experimental model of arthritis and suppressed the infiltration of inflammatory factors-expressing cells in the joint from CIA mice. Moreover, the number of pathogenic Th17 cells and inflammatory factors including TNF- $\alpha$ decreased while the number of regulatory $T$ cells increased in the spleen of the MTX-NPs-injected group. These findings suggest that MTX-NPs have potential as a more advanced therapeutic strategy to overcome the limitations of MTX therapy.

\section{Abbreviations}

RA: Rheumatoid arthritis; TNF: Tumor necrosis factor; IL: Interleukin; Th17: IL-17-producing T helper; MTX: Methotrexate; DMARD: Disease-modifying antirheumatic drug; NP: Nanoparticle; PVA: Polyvinyl alcohol; PLGA: Poly (D, L lactide-co-glycolide); H\&E: Hematoxylin and eosin; VEGF: Vascular endothelial growth factor; GC: Germinal center; P: Phosphorylated; Treg: Regulatory T; TEM: Transmission electron microscopy; Pdl: Polydispersity index; Breg: Regulatory B.

\section{Acknowledgements}

None.

\section{Authors' contributions}

JSP and DHL participated in the study design, data interpretation, and writing the manuscript. SCY, HYJ, HSN, KHC and JWC carried out the animal experiments and analyzed data. CWY and SHP participated in the study design and data interpretation. HK, MLC and SHP conceived and designed the study, interpreted the data, and made critical revisions of the manuscript for important intellectual content. All authors read and approved the final manuscript.

\section{Funding}

This research was supported by a grant of the Korea Health Technology R\&D Project through the Korea Health Industry Development Institute (KHIDI), funded by the Ministry of Health \& Welfare, Republic of Korea (grant number HI20C1496).

\section{Availability of data and materials}

All data are available in the manuscript or upon request to the authors.

\section{Declarations}

Ethics approval and consent to participate

All experimental procedures were examined and approved by the Animal Research Ethics Committee of the Catholic University of Korea; the procedure conformed to all National Institutes of Health of the United States guidelines (Permit number: 2020--0067-01).

\section{Consent for publication}

Not applicable.

\section{Competing interests}

The authors declare that they have no competing interests.

\section{Author details}

${ }^{1}$ The Rheumatism Research Center, Catholic Research Institute of Medical Science, College of Medicine, The Catholic University of Korea, 222, Banpo-daero, Seocho-gu, Seoul 06591, Republic of Korea. ${ }^{2}$ Department of Medical Life Sciences, College of Medicine, The Catholic University of Korea, 222 Banpo-daero, Seocho-gu, Seoul 06591, Republic of Korea. ${ }^{3}$ Department of Biomedicine and Health Sciences, College of Medicine, The Catholic University of Korea, 222 Banpo-daero, Seocho-gu, Seoul 06591, Republic of Korea. ${ }^{4}$ Division of Rheumatology, Department of Internal Medicine, School of Medicine, The Catholic University of Korea, Seoul St. Mary's Hospital, 222 Banpo-Daero, Seocho-gu, Seoul 137-701, South Korea. ${ }^{5}$ Lab of Translational ImmunoMedicine, Catholic Research Institute of Medical Science, College of Medicine, College of Medicine, The Catholic University of Korea, Seoul, Republic of Korea.

Received: 15 September 2021 Accepted: 18 January 2022

Published online: 11 February 2022

\section{References}

1. Feldmann M, Brennan FM, Maini RN. Rheumatoid arthritis. Cell. 1996;85:307-10.

2. Firestein GS. Invasive fibroblast-like synoviocytes in rheumatoid arthritis. Passive responders or transformed aggressors? Arthritis Rheum. 1996:39:1781-90.

3. Mclnnes IB, Schett $G$. The pathogenesis of rheumatoid arthritis. N Engl J Med. 2011;365:2205-19.

4. Hu Y, Cheng W, Cai W, Yue Y, Li J, Zhang P. Advances in research on animal models of rheumatoid arthritis. Clin Rheumatol. 2013;32:161-5.

5. Miossec P, Korn T, Kuchroo VK. Interleukin-17 and type 17 helper T cells. N Engl J Med. 2009;361:888-98.

6. Miossec P. IL-17 and Th17 cells in human inflammatory diseases. Microbes Infect. 2009;11:625-30.

7. Zhong Z, Wen Z, Darnell JE Jr. Stat3: a STAT family member activated by tyrosine phosphorylation in response to epidermal growth factor and interleukin-6. Science. 1994;264:95-8.

8. Yang XO, Panopoulos AD, Nurieva R, Chang SH, Wang D, Watowich SS, Dong C. STAT3 regulates cytokine-mediated generation of inflammatory helper T cells. J Biol Chem. 2007;282:9358-63.

9. Chabaud M, Durand JM, Buchs N, Fossiez F, Page G, Frappart L, Miossec P. Human interleukin-17: a T cell-derived proinflammatory cytokine produced by the rheumatoid synovium. Arthritis Rheum. 1999;42:963-70.

10. Chabaud M, Fossiez F, Taupin JL, Miossec P. Enhancing effect of IL-17 on IL-1-induced IL-6 and leukemia inhibitory factor production by rheumatoid arthritis synoviocytes and its regulation by Th2 cytokines. J Immunol. 1998;161:409-14

11. Koenders MI, Marijnissen RJ, Devesa I, Lubberts E, Joosten LA, Roth J, van Lent PL, van de Loo FA, van den Berg WB. Tumor necrosis factorinterleukin-17 interplay induces S100A8, interleukin-1 beta, and matrix metalloproteinases, and drives irreversible cartilage destruction in murine arthritis: rationale for combination treatment during arthritis. Arthritis Rheum. 2011;63:2329-39.

12. Shaw T, Quan J, Totoritis MC. B cell therapy for rheumatoid arthritis: the rituximab (anti-CD20) experience. Ann Rheum Dis. 2003;62(Suppl 2):ii55-59.

13. O'Neill SK, Shlomchik MJ, Glant TT, Cao Y, Doodes PD, Finnegan A. Antigen-specific B cells are required as APCs and autoantibody-producing cells for induction of severe autoimmune arthritis. J Immunol. 2005;174:3781-8

14. Swierkot J, Gruszecka K, Matuszewska A, Wiland P. Assessment of the effect of methotrexate therapy on bone metabolism in patients with rheumatoid arthritis. Arch Immunol Ther Exp (Warsz). 2015;63:397-404.

15. Khan ZA, Tripathi R, Mishra B. Methotrexate: a detailed review on drug delivery and clinical aspects. Expert Opin Drug Deliv. 2012;9:151-69.

16. Cronstein BN, Aune TM. Methotrexate and its mechanisms of action in inflammatory arthritis. Nat Rev Rheumatol. 2020;16:145-54.

17. Bijlsma JW, Jacobs JW. Methotrexate: still the anchor drug in RA treatment. Jt Bone Spine. 2009;76:452-4. 
18. Emery P, Sebba A, Huizinga TW. Biologic and oral disease-modifying antirheumatic drug monotherapy in rheumatoid arthritis. Ann Rheum Dis. 2013;72:1897-904.

19. Mount C, Featherstone J. Rheumatoid arthritis market. Nat Rev Drug Discov. 2005;4:11-2.

20. Yoon HY, Koo H, Choi KY, Chan Kwon I, Choi K, Park JH, Kim K. Photocrosslinked hyaluronic acid nanoparticles with improved stability for in vivo tumor-targeted drug delivery. Biomaterials. 2013;34:5273-80.

21. Thambi T, Deepagan VG, Yoon HY, Han HS, Kim SH, Son S, Jo DG, Ahn $\mathrm{CH}$, Suh YD, Kim K, et al. Hypoxia-responsive polymeric nanoparticles for tumor-targeted drug delivery. Biomaterials. 2014;35:1735-43.

22. Park JS, Jeong JH, Byun JK, Lim MA, Kim EK, Kim SM, Choi SY, Park SH, Min $\mathrm{JK}$, Cho ML. Regulator of Calcineurin 3 ameliorates autoimmune arthritis by suppressing Th17 cell differentiation. Am J Pathol. 2017;187:2034-45.

23. Brand DD, Latham KA, Rosloniec EF. Collagen-induced arthritis. Nat Protoc. 2007;2:1269-75.

24. Rosloniec EF, Cremer M, Kang A, Myers LK. Collagen-induced arthritis. Curr Protoc Immunol. 2001; Chapter 15:Unit 1515.

25. Iwamoto T, Okamoto H, Toyama Y, Momohara S. Molecular aspects of rheumatoid arthritis: chemokines in the joints of patients. FEBS J. 2008;275:4448-55.

26. Mellado M, Martinez-Munoz L, Cascio G, Lucas P, Pablos JL, RodriguezFrade JM. T cell migration in rheumatoid arthritis. Front Immunol. 2015;6:384.

27. Yang P, Qian FY, Zhang MF, Xu AL, Wang X, Jiang BP, Zhou LL. Th17 cell pathogenicity and plasticity in rheumatoid arthritis. J Leukoc Biol. 2019;106:1233-40.

28. Leipe J, Grunke M, Dechant C, Reindl C, Kerzendorf U, Schulze-Koops H, Skapenko A. Role of Th17 cells in human autoimmune arthritis. Arthritis Rheum. 2010;62:2876-85.

29. Lubberts E, Koenders MI, Oppers-Walgreen B, van den Bersselaar L, Coenen-de Roo CJ, Joosten LA, van den Berg WB. Treatment with a neutralizing anti-murine interleukin-17 antibody after the onset of collageninduced arthritis reduces joint inflammation, cartilage destruction, and bone erosion. Arthritis Rheum. 2004:50:650-9.

30. Friedman B, Cronstein B. Methotrexate mechanism in treatment of rheumatoid arthritis. Jt Bone Spine. 2019;86:301-7.

31. Spurlock CF 3rd, Gass HMT, Bryant CJ, Wells BC, Olsen NJ, Aune TM. Methotrexate-mediated inhibition of nuclear factor kappaB activation by distinct pathways in T cells and fibroblast-like synoviocytes. Rheumatology (Oxford). 2015;54:178-87.

32. Sung JY, Hong JH, Kang HS, Choi I, Lim SD, Lee JK, Seok JH, Lee JH, Hur GM. Methotrexate suppresses the interleukin-6 induced generation of reactive oxygen species in the synoviocytes of rheumatoid arthritis. Immunopharmacology. 2000;47:35-44.

33. Thomas S, Fisher KH, Snowden JA, Danson SJ, Brown S, Zeidler MP. Methotrexate is a JAK/STAT pathway inhibitor. PLoS ONE. 2015;10: e0130078.

34. Svensson L, Jirholt J, Holmdahl R, Jansson L. B cell-deficient mice do not develop type II collagen-induced arthritis (CIA). Clin Exp Immunol. 1998;111:521-6.

35. Yanaba K, Hamaguchi Y, Venturi GM, Steeber DA, St Clair EW, Tedder TF. B cell depletion delays collagen-induced arthritis in mice: arthritis induction requires synergy between humoral and cell-mediated immunity. J Immunol. 2007;179:1369-80.

36. Dahdah A, Habir K, Nandakumar KS, Saxena A, Xu B, Holmdahl R, Malin S. Germinal center B cells are essential for collagen-induced arthritis, Arthritis Rheumatol. 2018;70:193-203.

37. Matsushita T. Regulatory and effector B cells: friends or foes? J Dermatol Sci. 2019;93:2-7.

38. Shen P, Fillatreau S. Antibody-independent functions of B cells: a focus on cytokines. Nat Rev Immunol. 2015;15:441-51.

39. Rosser EC, Mauri C. Regulatory B cells: origin, phenotype, and function. Immunity. 2015;42:607-12.

40. Mantripragada S. A lipid based depot (DepoFoam technology) for sustained release drug delivery. Prog Lipid Res. 2002;41:392-406.

\section{Publisher's Note}

Springer Nature remains neutral with regard to jurisdictional claims in published maps and institutional affiliations.

Ready to submit your research? Choose BMC and benefit from:

- fast, convenient online submission

- thorough peer review by experienced researchers in your field

- rapid publication on acceptance

- support for research data, including large and complex data types

- gold Open Access which fosters wider collaboration and increased citations

- maximum visibility for your research: over $100 \mathrm{M}$ website views per year

At BMC, research is always in progress.

Learn more biomedcentral.com/submissions 